\title{
Application of the triacylglycerol/sterol condition index to the interpretation of larval lobster Homarus americanus distribution in close proximity to Georges Bank, Gulf of Maine
}

\author{
Gareth C. Harding ${ }^{1, *}$, Angus J. Fraser ${ }^{2}$ \\ ${ }^{1}$ Department of Fisheries and Oceans, Bedford Institute of Oceanography, PO Box 1006, Dartmouth, Nova Scotia B2Y 4A2, Canada \\ ${ }^{2} 33$ Battery Drive, Halifax, Nova Scotia B3P 2G9, Canada
}

\begin{abstract}
The triacylglycerol/sterol condition index was applied to larval lobster populations in the vicinity of Georges Bank in the Gulf of Maine. This index is related to larval size by an increasing power function which explains around $40 \%$ of the variation. The poor fit can be explained by the uneven increase in triacylglycerol levels during development within each moult stage. Increased pigmentation is not related to larval condition, as measured by lipid storage, and masks the increased yellowish hue of lipids as development proceeds. The larval triacylglycerol/sterol index appears to undergo a diurnal cycle in Stage III and IV lobsters, with lowest values at midday and highest values after dark. This pattern cannot be explained by nocturnal feeding, which leaves the possibilities that satiated larvae descend below the surface metre during daylight and are therefore underrepresented in our collections by being more vertically diffuse, and/or that healthy well-fed larvae would be more likely to detect the trawl and escape during daylight. Few Stage I and II lobster larvae were found in the vicinity of Georges Bank with a condition index less than 0.1, which is the level laboratory studies indicate approaches the 'point-of-no-return' The condition of all developmental stages was found to be better in individuals located off Georges Bank. This is not ecologically significant in the case of the first 2 stages because such a small proportion of the population was actually located off the bank. It is not resolved how the third and fourth stages arrive off Georges Bank, since shoal water hatching is the norm, but their lipid reserves are significantly greater than identical developmental stages located on the bank. Finally, the density of Stage IV larvae in the adjacent surface waters over the Gulf of Maine is twice that found over Georges Bank. This suggests that the lobster has evolved a life cycle in offshore waters in which larvae are hatched in shoal waters over the banks but the last 2 planktonic/pelagic stages either seek or are transported to, and by Stage IV thrive in, the warmer stratified layer over the deeper waters of the Gulf of Maine.
\end{abstract}

KEY WORDS: Triacylglycerols - Sterols - Condition index - American lobster larvae - Homarus americanus - Georges Bank · Gulf of Maine

\section{INTRODUCTION}

Interest has been growing in the possibility that lobster larvae from offshore banks might drift with the residual currents and/or navigate towards the coast and recruit to the more coastal waters (Rogers et al. 1968, Stasko 1978, Fogarty et al. 1980, Harding et al. 1983, Harding \& Trites 1988, 1989, Katz et al. 1994). Larval distributional studies in Canadian offshore

\footnotetext{
•E-mail: hardingg@mar.dfo-mpo.gc.ca
}

waters indicate that lobster eggs are hatched in the shoaler waters of Georges, Browns and German Banks (Stasko \& Gordon 1983, Watson \& Miller 1991, Harding et al. 1995), whence they become part of the summer, surface-water, plankton community (Harding et al. 1983). From here, they are believed to be widely broadcast by the time they moult into the fourth and final planktonic/pelagic stage and before seeking the bottom. A greater density of Stage IV lobsters was observed off rather than on Georges Bank during an August and several July surveys in the 1980s (Harding et al. 1995). It is not known how substantial numbers of 
lobster larvae escape the retentive hydrography of the offshore banks (Loder et al. 1993, Perry et al. 1993, Tremblay et al. 1994, Harding et al. 1995). The aspect addressed here is whether larvae located off the bank are in as good a condition for survival as those remaining over the bank.

A number of fish studies on the NW Atlantic shelf have addressed the issue of larval condition and local hydrography (Frank \& McRuer 1989). Haddock larvae fared better in surface waters that were stratified (Buckley \& Lough 1987, Frank \& McRuer 1989), whereas cod appeared to do best in mixed waters (Koslow et al. 1985, Buckley \& Lough 1987) regardless of the proximity of Browns, Georges or German Bank. There was no obvious relationship between larval herring condition and proximity to Georges Bank (Cohen et al. 1980).

A variety of condition indices have been developed in an attempt to evaluate the survival potential for planktonic larval fishes, which includes morphometric, histological and biochemical characteristics (Ferron \& Leggett 1994). Fraser et al. (1987) and Hakanson $(1989 a, b)$ suggest lipid class composition as a good indication of nutritional condition. It is well known that triacylglycerol is a common form of energy storage in animals (Sargent \& Whittle 1981). Sasaki (1984) measured the type and concentrations of lipids in larval lobsters during laboratory growth and starvation studies and found that triacylglycerol content was a good indicator of their nutritional history. Fraser (1989) reexamined these data and concluded that triacylglycerol content, by itself, was not a good indication of lobster condition because of its dependence on larval size. Fraser proposed accounting for body size by using a ratio of triacylglycerol to sterol concentrations, because sterols were found to be directly proportional to body dry weight and were not significantly catabolized during 5 to 6 d starvation (Sasaki 1984). However, there is always a problem with relating larval condition from laboratory to field conditions (Hakanson 1989a). In the present paper we attempt to evaluate the use of the triacylglycerol/sterol ratio as a condition index for lobster larvae collected from 2 water masses in the vicinity of Georges Bank.

\section{METHODS}

Larval lobsters were collected for lipid analysis on 3 oceanographic cruises to the Canadian sector of Georges Bank. In 1988 transects were run across the northern frontal zone on Georges Bank between 5 and 21 July ('Lady Hammond' Cruise 187) and between 23 August and 1 September ('Lady Hammond' Cruise 191) as part of a joint physical-biological study (see
Perry et al. 1993). Lobster larvae were captured with a Vass-Tucker trawl $\left(-2.5 \mathrm{~m}^{2}\right.$ effective mouth size, $1.6 \mathrm{~mm}$ mesh) from an integrated tow of $30 \mathrm{~min}$ duration above ( 70 trawls) and below (63 trawls) the pycnocline, together with continuously recorded temperature, salinity (conductivity), light intensity, depth and volume of seawater filtered (Vass 1988). Four surface trawls were taken. In 1989, transects were again run across the northern section of the bank and 6 deployments of internally recording Loran-C drifters, with $5 \mathrm{~m}$ long drogues centered at $10 \mathrm{~m}$ depth, were followed for $2 \mathrm{~d}$ periods from 3 on-bank and 3 off-bank starting locations (July 12 to 31 , 'Lady Hammond' Cruise 202, see Drinkwater et al. 1992, Harding et al. 1995). Three drifters were followed consecutively on each of the 2 sets for larval lobster sampling. One surface (total: 20 trawls) and 3 stepped, oblique integrated Vass-Tucker trawls, of $30 \mathrm{~min}$ duration, from close to the bottom or from $50 \mathrm{~m}$ depth to the surface in deeper waters (100 trawls) were carried out in the vicinity of each drifter before steaming to the next drifter. At the end of the 1989 cruise, one of our transect lines of oblique trawls was continued out into the Gulf of Maine proper in search of the more advanced planktonic stages of the lobster.

At sea, larval lobsters were sorted from the macroplankton catch, the carapace length was measured, colour was noted, and then the larvae were identified to moult and intramoult stage, using the descriptions of Aiken (1973) and Sasaki (1984), usually within $30 \mathrm{~min}$ of trawl retrieval. Of these larvae, selected living individuals of a variety of stages were individually rolled in aluminum foil, placed in glass vials and frozen in liquid nitrogen for later lipid analysis in the laboratory onshore. It was not always possible to capture intramoult Substages A and B alive, especially Stage I larvae, because of their vulnerable state due to soft exoskeletons, so recently dead or nearly dead individuals had to suffice for lipid determinations. On returning to port, the vials were transferred to a $-70^{\circ} \mathrm{C}$ freezer until analysis 2 to 4 mo later. Sasaki \& Capuzzo (1984) found no evidence of enzymatic or oxidative degradation of various neutral or polar lipids over a period of $105 \mathrm{~d}$ if the lobster larvae were frozen immediately in liquid nitrogen and stored at $-70^{\circ} \mathrm{C}$. Lipid quantification was performed using the Iatroscan thinlayer chromatography-flame ionization detection system (Ackman 1981, Fraser et al. 1985). This method is applicable to the analysis of a single fish larvae containing $0.9 \mu \mathrm{g}$ of triacylglycerol (Fraser et al. 1988). Larvae were individually freeze-dried for $24 \mathrm{~h}$ and weighed to the nearest $0.01 \mathrm{mg}$ dry weight. Lipid was extracted by placing individual larvae in $2 \mathrm{ml}$ of dichloromethane-methanol $(2: 1, v / v)$ for about $18 \mathrm{~h}$, following the addition of a known amount of nonade- 
cane internal standard. Solvent was then removed by syringe and the defatted carcass rinsed with a further $1 \mathrm{ml}$ of solvent. A more conventional extraction (Fraser et al. 1987) of a selection of the defatted carcasses produced no further lipid. The main advantage of the passive method of lipid extraction was that by eliminating the formation of an aqueous phase there was no incidence of water residue contaminating the small lipid samples. Triacylglycerols and sterols were quantified on an Iatroscan Mark III (Iatron Laboratories, Tokyo, Japan), using synthetic standards (Fraser et al. 1985). Chromarods were developed initially in hexanediethyl ether-formic acid $(82: 2.5: 0.045, \mathrm{v} / \mathrm{v} / \mathrm{v})$ to permit separation of the nonadecane and sterol esters. A subsequent development in hexane-diethyl ether-formic acid $(55.2: 29.7: 0.075, \mathrm{v} / \mathrm{v} / \mathrm{v})$ separated the sterols, free fatty acids and triacylglycerol. Any non-lipid material that contaminated the passively extracted lipid remained at the spotting origin of the chromarods and did not interfere with the migration of the lipid classes.

Parametric or nonparametric statistics were calculated as indicated in the text where appropriate with the SYSTAT package for Macintosh, version 5.2 (Wilkinson 1992). Normality of variables was checked before performing statistics using the Lilliefores test with the Kolmogorov-Smirnov programme. The significance level chosen throughout was $\mathrm{p}<0.05$.

\section{RESULTS AND DISCUSSION}

\author{
Lipid, mass and size relationships
}

It has been proposed that storage lipids of individual lobster larvae would be a logical indication of their nutritional condition (Fraser 1989). In experimental studies with lobster larvae it was found that triacylglycerols served as the storage lipid utilized first under starvation conditions, whereas sterols, the other major neutral lipid in lobster, remained approximately constant relative to protein levels (Sasaki 1984). Triacylglycerol concentrations are known to be a function of larval size (Sasaki 1984), thus any lipid-based condition index must be normalized by some measure of organism size (Fraser 1989).

Lobster larvae retained from the neighbourhood of Georges Bank in the present study were examined first for possible effects of collection month and year on lipid type, larval size and biomass (Table 1). No difference was observed between collection month and year in dry weight, carapace length, intramoult stage, triacylglycerol and sterol content of Stage I and II lobsters. Stage III and IV lobsters, however, weighed significantly more and contained a greater body content of sterols in the August collections. Stage IV lobsters also had greater triacylglycerol stores in August compared

Table 1 A comparison of dry weight, carapace length, intramoult stage, triacylglycerol (TAG) and sterol (ST) content and the TAG/ST ratio ( $x \pm$ SD, number of individuals given in parentheses) of lobster moult Stages I to IV collected during 5 to 21 July 1988, 23 August to 1 September 1988, and 12 to 31 July 1989

\begin{tabular}{|c|c|c|c|c|c|}
\hline & $\begin{array}{l}\text { Collection } \\
\text { date }\end{array}$ & I & $\begin{array}{l}\text { Lobster moult stages } \\
\text { II }\end{array}$ & III & IV \\
\hline $\begin{array}{l}\text { Dry weight } \\
\text { (g) }\end{array}$ & $\begin{array}{l}\text { Jul } 1988 \\
\text { Aug } 1988 \\
\text { Jul } 1989\end{array}$ & $\begin{array}{l}1.78 \pm 0.34(17) \\
1.47 \quad(1) \\
1.66 \pm 0.32(64)\end{array}$ & $\begin{array}{l}3.66 \pm 0.81(10) \\
3.22 \pm 0.40 \quad(3) \\
3.33 \pm 0.71(76)\end{array}$ & $\begin{array}{l}6.19 \pm 2.06(4)^{\mathrm{ab}} \\
7.87 \pm 1.22(16)^{\mathrm{b}} \\
6.60 \pm 1.48(59)^{\mathrm{a}}\end{array}$ & $\begin{array}{c}- \\
23.0 \pm 5.4(37)^{\mathrm{a}} \\
16.9 \pm 5.8(42)^{\mathrm{a}}\end{array}$ \\
\hline $\begin{array}{l}\text { Carapace } \\
\text { length } \\
(\mathrm{mm})\end{array}$ & $\begin{array}{l}\text { Jul } 1988 \\
\text { Aug } 1988 \\
\text { Jul } 1989\end{array}$ & $\begin{array}{l}2.09 \pm 0.11(13) \\
2.04 \quad(1) \\
2.09 \pm 0.09(62)\end{array}$ & $\begin{array}{l}2.95 \pm 0.12(10) \\
2.88 \pm 0.12(3) \\
2.96 \pm 16.2(76)\end{array}$ & $\begin{array}{l}3.70 \pm 0.04(4)^{\mathrm{ab}} \\
3.87 \pm 0.17(16)^{\mathrm{a}} \\
3.97 \pm 0.21(60)^{\mathrm{b}}\end{array}$ & $\begin{array}{c}4.9 \pm 0.2(37) \\
4.9 \pm 0.2(42)\end{array}$ \\
\hline $\begin{array}{l}\text { Intramoult } \\
\text { stage } \\
(1-10)\end{array}$ & $\begin{array}{l}\text { Jul } 1988 \\
\text { Aug } 1988 \\
\text { Jul } 1989\end{array}$ & $\begin{array}{l}3.8 \pm 0.8(17) \\
4.0 \\
3.4 \pm 1.5(62)\end{array}$ & $\begin{array}{l}5.0 \pm 2.5(10) \\
4.3 \pm 1.5(3) \\
4.5 \pm 1.5(77)\end{array}$ & $\begin{array}{l}4.0 \pm 2.7(4) \\
5.5 \pm 1.8(16) \\
5.1 \pm 2.4(60)\end{array}$ & $\begin{array}{c}- \\
3.4 \pm 0.6(37) \\
3.2 \pm 0.9(42)\end{array}$ \\
\hline $\begin{array}{l}\text { Triacylglycerol } \\
(\mu g)\end{array}$ & $\begin{array}{l}\text { Jul } 1988 \\
\text { Aug } 1988 \\
\text { Jul } 1989\end{array}$ & $\begin{array}{l}2.17 \pm 0.78(17) \\
2.32 \quad(1) \\
3.96 \pm 4.65(64)\end{array}$ & $\begin{aligned} 5.0 & \pm 2.5(10) \\
11.7 & \pm 14.9 \quad(3) \\
14.2 & \pm 19.6(77)\end{aligned}$ & $\begin{array}{l}71.2 \pm 51.7(4) \\
39.7 \pm 38.4(16) \\
65.9 \pm 82.9(60)\end{array}$ & $\begin{array}{c}- \\
854.1 \pm 671.9(37)^{\mathrm{a}} \\
458.3 \pm 445.1(42)^{\mathrm{a}}\end{array}$ \\
\hline $\begin{array}{l}\text { Sterol } \\
(\mu g)\end{array}$ & $\begin{array}{l}\text { Jul } 1988 \\
\text { Aug } 1988 \\
\text { Jul } 1989\end{array}$ & $\begin{array}{l}12.7 \pm 5.4(17) \\
10.7 \quad(1) \\
11.7 \pm 3.5(64)\end{array}$ & $\begin{array}{l}25.1 \pm 6.4(9) \\
20.0 \pm 3.3(3) \\
21.8 \pm 5.5(76)\end{array}$ & $\begin{array}{l}35.2 \pm 10.1(4)^{\mathrm{a}} \\
51.7 \pm 10.4(16)^{\mathrm{ab}} \\
37.7 \pm 10.7(60)^{\mathrm{b}}\end{array}$ & $\begin{array}{c}- \\
93.7 \pm 24.3(37)^{\mathrm{a}} \\
63.2 \pm 17.7(42)^{\mathrm{a}}\end{array}$ \\
\hline TAG/ST & $\begin{array}{l}\text { Jul } 1988 \\
\text { Aug } 1988 \\
\text { Jul } 1989\end{array}$ & $\begin{array}{l}0.18 \pm 0.07(17) \\
0.22 \quad(1) \\
0.36 \pm 0.45(64)\end{array}$ & $\begin{array}{l}0.18 \pm 0.06(9) \\
0.53 \pm 0.62(3) \\
0.68 \pm 0.96(75)\end{array}$ & $\begin{array}{l}1.84 \pm 1.28(4) \\
0.77 \pm 0.70(16) \\
1.76 \pm 2.17(60)\end{array}$ & $\begin{array}{c}- \\
8.57 \pm 5.92(37) \\
6.74 \pm 6.15(42)\end{array}$ \\
\hline
\end{tabular}



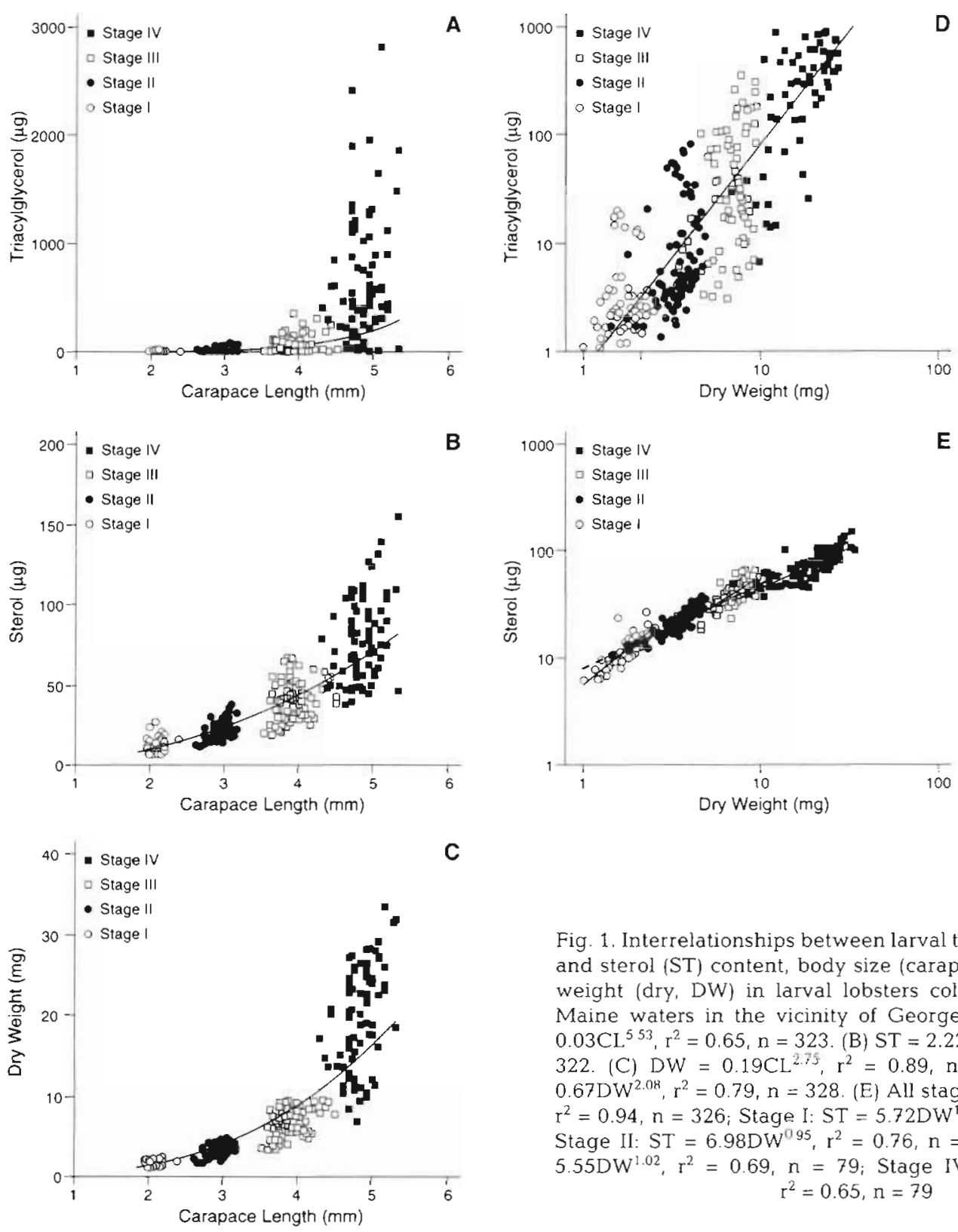

Fig. 1. Interrelationships between larval triacylglycerol (TAG) and sterol (ST) content, body size (carapace length, CL) and weight (dry, DW) in larval lobsters collected from Gulf of Maine waters in the vicinity of Georges Bank. (A) TAG = $0.03 \mathrm{CL}^{53.3}, \mathrm{r}^{2}=0.65, \mathrm{n}=323$. (B) $\mathrm{ST}=2.22 \mathrm{CL}^{2.15}, \mathrm{r}^{2}=0.84, \mathrm{n}=$ 322. (C) $\mathrm{DW}=0.19 \mathrm{CL}^{2.75}, \mathrm{r}^{2}=0.89, \mathrm{n}=321$. (D) $\mathrm{TAG}=$ $0.67 D W^{2.08}, r^{2}=0.79, n=328$. (E) All stages: $S T=8.09 D W^{0.78}$, $r^{2}=0.94, n=326 ;$ Stage I: ST $=5.72 D^{1.33}, r^{2}=0.67, n=82$; Stage II: $\mathrm{ST}=6.98 \mathrm{DW} \mathrm{W}^{095}, \mathrm{r}^{2}=0.76, \mathrm{n}=86_{i}$ Stage III: $\mathrm{ST}=$ $5.55 \mathrm{DW}^{1.02}, \mathrm{r}^{2}=0.69, \mathrm{n}=79 ;$ Stage IV: $\mathrm{ST}=8.16 \mathrm{DW} \mathrm{W}^{0.75}$, $r^{2}=0.65, n=79$

to in July. As expected, expressing triacylglycerol content as a ratio of sterol content had the effect of normalizing the lipid storage to body biomass (Table 1).

The total lobster larvae collected in the present study $(\mathrm{n}=328)$ were first used to examine the relationships in the wild between major neutral lipid types, body size and biomass (Fig. 1A-E). In all cases, these variables were best fitted by exponential and/or power functions; the latter are illustrated in the figure because of their greater flexibility to fit either differentially increasing or decreasing values. Larval lobster biomass, expressed as dry weight, is related to the linear dimension of carapace size to the power of 2.75 (Fig. 1C), which is close to the average value of 2.83

obtained from observations on a broad spectrum of organisms (Peters 1983). The increase in variability of dry weight with developmental stage (Fig. 1C) is an artifact of the scale used because growth is exponential and not linear. Dry weight is a more useful measure of body size than carapace length for the present purposes, because more of the variability is accounted for when either storage or structural lipid types are plotted against dry weight and fitted to a power function (Fig. 1D,E).

Sterols are important components of cellular membranes (Bloch 1983). Fraser (1989) reported a good linear correlation between these structural neutral lipids (1ug) and the dry weight of individual lobster larvae 
using the experimental data of Sasaki (1984), and suggested that sterols might be a better proxy of organism size than dry weight because of the possible loss of storage lipids while obtaining freeze-dried weights. The present study found this latter concern was unfounded because freeze-drying lobster larvae did not result in measurable lipid hydrolysis. Nevertheless, the present data do not support a linear relationship in nature between sterol content and dry weight of lobster larvae (Fig. 1E). A power curve with an exponent of $0.78\left(r^{2}=0.94\right)$ is the best fit to the Georges Bank larval data. This divergence from a simple, linear relationship can be explained by several observations. First, a better measure of living biomass than dry weight is the protein content of the organism. Sasaki's (1984) study has shown that dry weight is a poor predictor of protein content whereas sterols are directly proportional to protein with a constant sterol/protein ratio of $1.7 \pm 0.2 \%$ throughout larval development. This poor relationship between dry weight and protein weight can, in part, be attributed to the measured larval ash weight (14 to $34 \%$ dry weight), which levels off prior to each moult, then increases rapidly during calcification of the new exoskeleton (Sasaki 1984). Larval sterol, however, increases more continuously throughout development, which results in the 'sawtooth' appearance of the plot of sterols versus dry weight (Fig. 1E). If moult stages are fitted separately to power curves, it is apparent that the sterol-dry weight relationship of Stage I has an exponent $>1$ (1.3), Stages II and III have exponents close to 1, i.e. a linear function, and Stage IV has an exponent of 0.75 . This means that proportionately more sterols are accumulated in first feeding larvae relative to their dry weight and that proportionately less sterols are stored during fourth stage development. Williams (1907) noted that calcification of the exoskeleton commences after the larvae moult into the fourth or megalopal larval stage (see Williamson 1969). Sasaki's (1984) laboratory results are consistent with this because larval ash content increased by 4 -fold during metamorphosis. However, ash content doubled between Stage I and Stage III lobsters (Sasaki 1984), which means that mineralization of the exoskeleton in fact progresses throughout larval development. Development changes in ash weight probably cause the disproportional decrease in larval sterol concentrations relative to dry weight over the planktonic-pelagic larval phase of the lobster (Fig. 1E).

Sasaki's (1984) laboratory study of lipid type and concentration in larval lobster found that triacylglycerol accumulation started around the middle of Stage II, increased exponentially to Stage $\mathrm{IVD}_{1}$, then leveled out for the remainder of Stage IV. The triacylglycerol content of lobster larvae collected in the vicinity of Georges Bank plotted against dry weight were best fitted with a power function with an exponent of 2.1 (Fig. 1D). There was much more variability in the triacylglycerol content $\left(r^{2}=0.79\right)$ compared to the sterol content $\left(r^{2}=0.94\right)$, which is readily explained by the former being the main storage lipid of larval lobsters and the first to be utilized for energy during food shortages (Sasaki 1984). Hakanson (1989a) reported similar observations on wild anchovy larvae, where the power relationship between triacylglycerol or polar lipids and size has considerably more variation than that between cholesterol and size. This variation was readily explained from the results of their starvation studies, where triacylglycerol decreased first, then to a lesser degree so did polar lipids, whereas cholesterol levels remained constant. In nature, this would translate into higher triacylglycerol variability because of the different feeding histories of individual larvae (Hakanson 1989b).

\section{Lipid condition indices}

Condition indices have been created for use with various marine organisms by normalizing the quantity of storage lipids present to their body mass (Ouellet et al. 1992, 1995, Lovrich \& Ouellet 1994), body size (Suthers et al. 1992) or some type of structural lipid, either sterols (Fraser 1989) or phospholipids (Chandumpai et al. 1991). Lochmann et al. (1995) used a condition index for cod larvae based on discriminant analysis using triacylglycerol, phospholipid content and defatted dry weight.

Triacylglycerol/sterol and triacylglycerol/dry weight ratios are evaluated here to describe the nutritional conditions of lobster larvae collected in the neighbourhood of Georges Bank. It can be seen that these indices give similar results when plotted against a linear measure of larval size (Fig. 2). Both condition indices give variable results but the data is reasonably fitted, $-40 \%$ variation explained, by increasing power functions with exponents of 3.4 and 2.8 , respectively. These results are not surprising given that sterols are an integral component of cellular membranes (Bloch 1983) and that dry weight is a measure of mass, albeit influenced by developmental changes in chitinization and calcification of lobster larvae (Sasaki 1984). These results show that the larval condition index, or relative energy reserves, increases exponentially from Stage I to Stage IV lobsters and that this is accompanied by an apparent greater range of variation in condition as development proceeds.

The triacylglycerol/sterol index was chosen over the triacylglycerol/dry weight index because sterol content is directly proportional to protein content and therefore a better proxy for living biomass than dry 


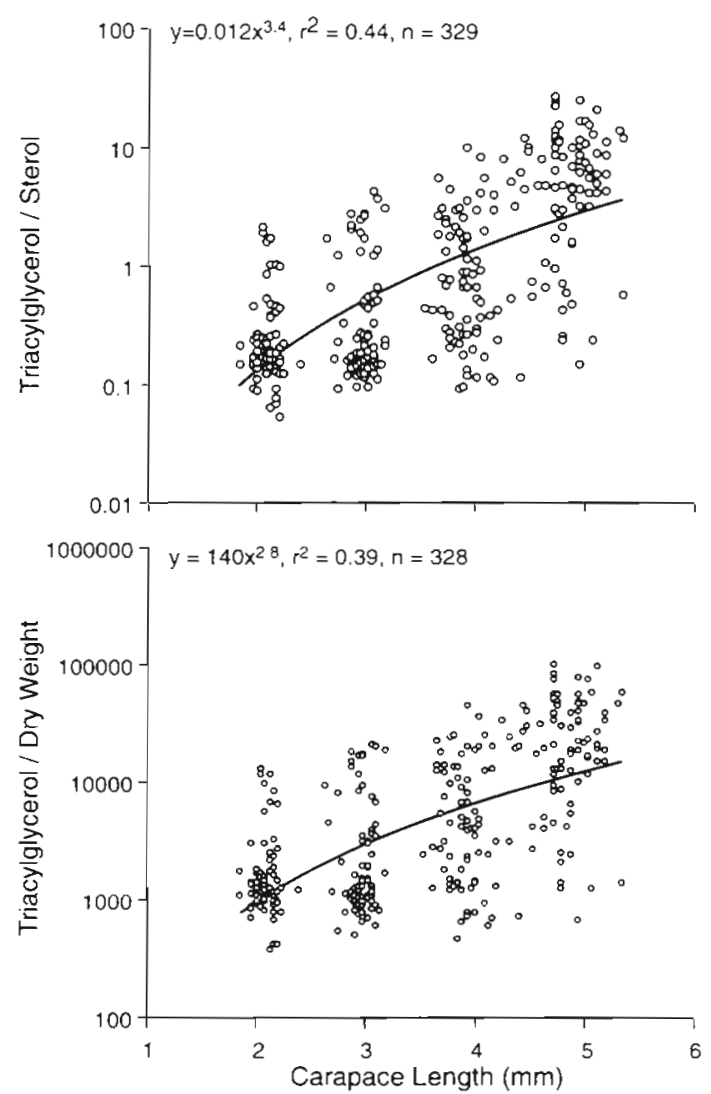

Fig. 2. Relationship between 2 condition indices, triacylglycerol/sterol and triacylglycerol/dry weight ratios, and larval lobster size from collections taken in the Gulf of Maine in the vicinity of Georges Bank

weight. In the following sections, the characteristics of the triacylglycerol/sterol index is first assessed with regard to larval development, colour and day-night variation. At this point, it is not clear what value of the condition index is required for successful moulting of larvae and/or settlement of Stage IV larvae to the bottom or, indeed, whether larvae delay moulting or settlement until sufficient energy stores have been acquired. This issue of larval survival is addressed with a reanalysis of the earlier starvation studies of Sasaki (1984). Finally, condition indices are used to interpret the known larval lobster geographical distribution in the vicinity of Georges Bank.

\section{Intramoult stage effects on condition indices}

Lobster larvae collected in the Georges Bank region were used to examine the relationship between larval triacylglycerol content and the developmental progression within each moult stage (intramoult staging; Fig. 3). Sasaki et al. (1986) have shown that triacylglycerol content in cultured lobster larvae increased exponentially from the middle of the second moult stage until levels plateaued after Stage IVD. The triacylglycerol levels in the present collection of wild lobsters also increased exponentially with intramoult stage progression from Stage I to Stage $\operatorname{IVD}_{1}(y=0.92$ $\times 10^{0.07 x}, \mathrm{r}^{2}=0.70$ ). However, as previously noted, there is a between-moult pattern of triacylglycerol content not taken into account by this equation with levels increasing up to intramoult Substage $D_{1}$ in lobster Stages I to III and intramoult Substage $D_{0}$ in Stage IV lobsters before declining during premoult (intramoult Substages $D_{0}$ to $D_{3}$, Fig. 3). The sterol content of wild lobster larvae also increased from moult to well into premoult, followed by near constant levels in late premoult (Fig. 3). The sterol body burdens plotted against intramoult Stages IA to IVD, are less variable and provide a better fit to an exponential equation than triacylglycerol concentrations $\left(y=8.9 \times 10^{0027 x}, \mathrm{r}^{2}=0.86\right)$. It is not surprising, then, that the triacylglycerol/sterol condition index mirrors the triacylglycerol concentrations in the lobster larvae (Fig. 3). Previously, Fraser (1989) had demonstrated that minor inflections occur near moulting in Homarus americanus when the triacylglycerol/sterol ratio was plotted against the development time, using the cultivated larval growth data of Sasaki (1984). This phenomenon appears to be widespread, being observed in the shrimp Pandalus (Ouellet et al. 1992) and Panaeus (Chandumpai et al. 1991) and the crab Hyas (Anger \& Dawirs 1981, Anger et al. 1989) and Chioneocetes (Lovrich \& Ouellet 1994).

This intramoult variation of the triacylglycerol/sterol ratio needs to be considered if this index is to be used as a measure of larval condition. This conclusion would apply also to the use of the triacylglycerol/dry weight ratio as a measure of larval condition.

\section{Colour and intramoult development}

In the pigmentless state, lobster larvae appear bluish due to the hemolymph copper-containing protein molecule hemocyanin (Goodwin 1960). In Georges Bank larvae this colour is most frequently seen in the first developmental stage, often in combination with the yellowish hue of lipids associated with the digestive tract (Fig. 4). However, blue lobsters occurred sporadically in our collections up to development Stage IVC. Red pigmentation commences in the first stage lobster at the base of the appendages, by incorporating carotenoids from their prey. Crustaceans are unable to produce these compounds de novo but obtain them directly or indirectly from phytoplankton (Herring 1972). It is clear from the appearance of pigmentation in the Georges Bank larvae that most lobsters commence feeding by Stage IB (Fig. 4). In general, as 


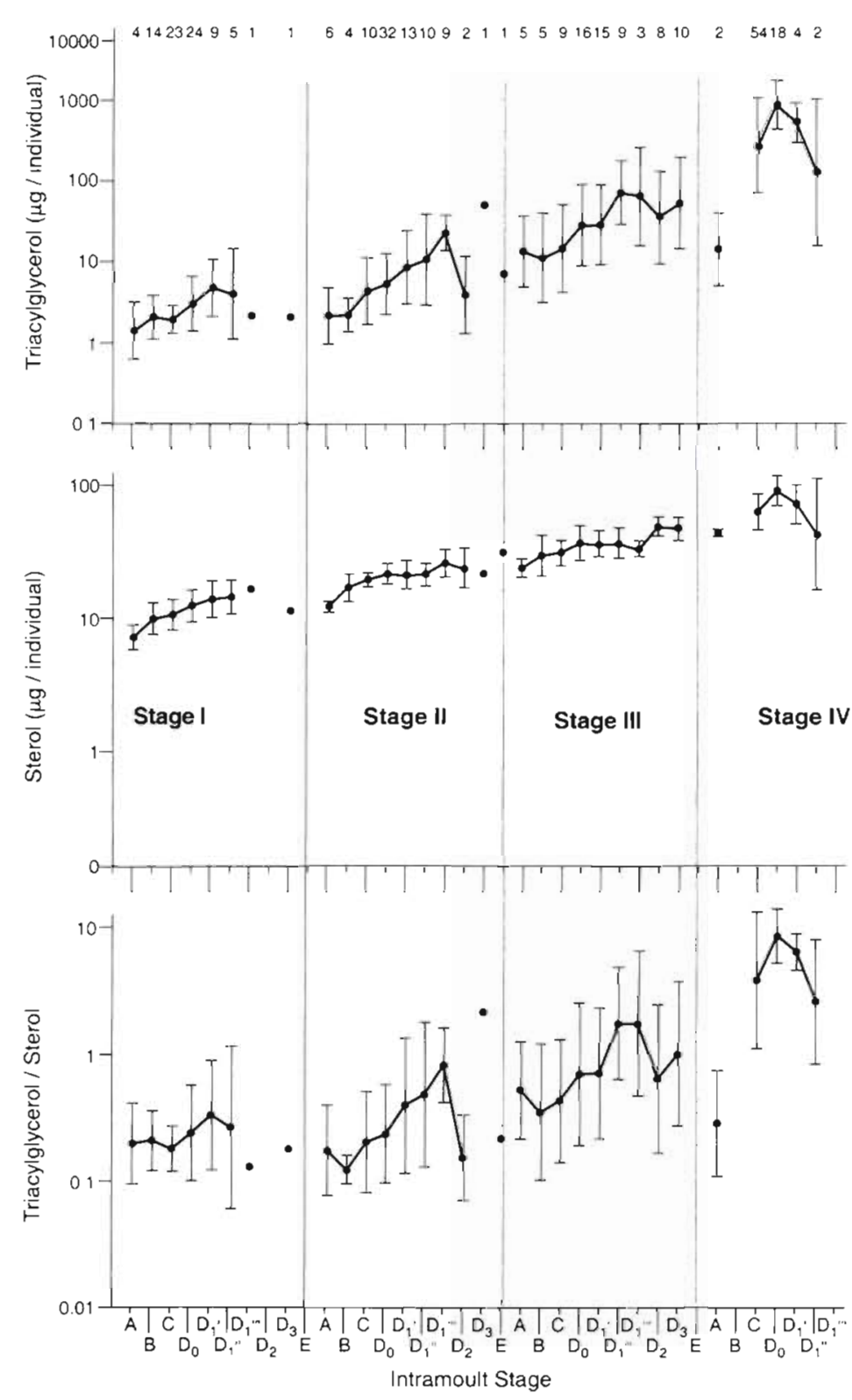

Fig. 3. Larval triacylglycerol and sterol content and their ratio plotted against intramoult and moult stages of lobster collected in the vicinity of Georges Bank, Gulf of Maine. Geometric means and standard deviations are shown. Individual intramoult sample sizes are displayed at the top of the graph. E: moulting or ecdysis

development proceeds larval pigmentation increases such that Stage III and IV lobster are often various intensities of a red, brown and/or a green colouration (Fig. 4). There was no relationship between relative lipid levels, expressed as triacylglycerol/sterol ratios, and colouration of wild lobster larvae, as evidenced by the extensive overlap of the $\pm \mathrm{SD}$ error (Fig. 4). For example, the less pigmented Stage IVC individuals had triacylglycerol/sterol ratios which were not significantly different from those of the darker coloured lob- sters (Kruskal-Wallis 1-way ANOVA), Thus, bluish individuals appear to be in a comparable state of health to darker pigmented larvae. The most likely explanation is that the bluish lobsters had their carotenoid pigmentation concealed by the astaxanthin-binding protein, $\alpha$-crustacyanin, shifting the combined absorption to the blue end of the visual spectrum (Keen et al. 1991, Zagalsky et al. 1991). It is also conceivable that the more neustonic individuals can conceal their pigmentation in this manner to avoid the attention of predators. However, it is not possible with the present collections to distinguish whether the bluer individuals are present at different depths in nature. In conclusion, increased pigmentation bears no obvious relationship to larval condition, as measured by lipid storage, and masks the increased yellowish hue of lipids as development proceeds.

\section{Larval condition index and the daily light regime}

The triacylglycerol/sterol index values for all lobster larvae collected from the Georges Bank region were plotted against the corresponding light levels measured in near-surface $(0.1$ to $0.25 \mathrm{~m})$ waters and found to fit an exponentially decreasing function best (Fig. 5). However, this equation accounts for only $18 \%$ of the variation, since most of the larvae were collected in light levels less than $10 \mu \mathrm{E} \mathrm{m}^{-2} \mathrm{~s}^{-1}$ while most of the decline in larval condition occurs at light levels greater than $100 \mu \mathrm{E} \mathrm{m}^{-2} \mathrm{~s}^{-1}$ (daylight). Breaking this relationship down by moult stage, it was found that the first 3 larval stages are responsible, to a large part, for this declining trend of condition index versus near-surface light intensity. Only 5 out of 82 Stage IV lobster analyzed for lipid content was captured in light intensities exceeding $100 \mu \mathrm{E} \mathrm{m}^{-2} \mathrm{~s}^{-1}$.

If triacylglycerol/sterol values for all developmental stages from all cruises are plotted on a $24 \mathrm{~h}$ scale, it appears that a cycle exists with the lowest values occurring during the middle of the day and progressively higher values occurring after dusk, until early morning, when the whole sequence reverses (Fig. 6A). Furthermore, when this data set is presented relative to developmental stage, it is clear that the third and fourth stage lobsters combined account for much of this variability (see sine function fitted to Stage III and 
Table 2. Calculated average daily consumption of triacylglycerol by Stage III and IV lobsters. SD: standard deviation; CI: confidence intervals

\begin{tabular}{|c|c|c|c|}
\hline Prey species & $\begin{array}{c}\text { Prey triacylglycerol } \\
\left(\mu g \text { copepod }{ }^{-1} ; x \pm S D\right)\end{array}$ & $\begin{array}{l}\text { No. prey eaten }{ }^{d} \\
\left(d^{-1} ; x \pm S D\right)\end{array}$ & $\begin{array}{c}\text { Triacylglycerol consumed } \\
\left(\mu \mathrm{g} \text { lobster } \mathrm{d}^{-1} ; \mathrm{x}, 95 \% \mathrm{CI}\right)\end{array}$ \\
\hline \multicolumn{4}{|l|}{ (A) Stage III lobster ( $\mathbf{n}=\mathbf{8}$ ) } \\
\hline Calanus finmarchicus $\mathrm{CV}^{\mathrm{b}}$ & $\begin{array}{c}0.98 \pm 0.13^{\mathrm{d}} \\
(0.63 \pm 0.28)^{\mathrm{e}}\end{array}$ & $3.0 \pm 2.0$ & $2.94\{0-8.6\}$ \\
\hline Temora longicornis $\mathrm{AF}^{\mathrm{C}}$ & $0.79 \pm 0.02^{d}$ & $2.6 \pm 2.8$ & $2.05(0-6.8)$ \\
\hline Pseudocalanus sp. AF & $\begin{array}{c}0.23 \pm 0.02^{\mathrm{d}} \\
(0.21 \pm 0.31)^{\mathrm{e}}\end{array}$ & $1.7 \pm 3.0$ & $0.39(0-2.1)$ \\
\hline Acartia hudsonica AF & $0.45 \pm 0.05^{e}$ & $2.1 \pm 2.5$ & $0.95(0-3.9)$ \\
\hline Total & & & 6.33 \\
\hline \multicolumn{4}{|l|}{ (B) Stage IV lobster $(n=6)$} \\
\hline Calanus finmarchicus $\mathrm{CV}$ & $\begin{array}{r}0.98 \pm 0.13^{\mathrm{d}} \\
(0.63 \pm 0.28)^{\mathrm{e}}\end{array}$ & $8.1 \pm 5.7$ & $7.94(0-24.2)$ \\
\hline Temora longicornis AF & $0.79 \pm 0.02$ & $18.6 \pm 6.3$ & $14.69(4.5-25.9)$ \\
\hline Pseudocalanus sp. AF & $\begin{array}{c}0.23 \pm 0.02^{d} \\
(0.21 \pm 0.31)^{\mathrm{e}}\end{array}$ & $4.5 \pm 1.6$ & $1.04(0.2-2.1)$ \\
\hline Acartia hudsonica AF & $0.45 \pm 0.05^{\mathrm{e}}$ & $17.5 \pm 3.5$ & $7.88(3.7-13.5)$ \\
\hline Total & & & 31.54 \\
\hline \multicolumn{2}{|c|}{$\begin{array}{l}\text { "G. Harding, unpublished prey selection experiments in } \\
\text { which } 4 \text { prey types most likely to be encountered and con- } \\
\text { sumed in the wild were presented to Stage III and IV lob- } \\
\text { sters in } 4 \text { I jars over } 24 \text { h. Twenty and thirty copepods of } \\
\text { each prey type were presented to Stage III and Stage IV } \\
\text { lobsters, respectively }\end{array}$} & 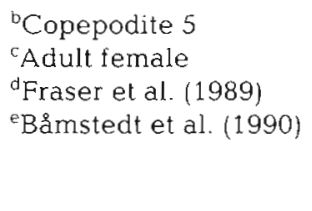 & \\
\hline
\end{tabular}

lobsters analyzed for lipid here, a total of 3, 188 and 157 Stage III and IV lobsters combined were captured below the pycnocline, above the pycnocline and at the surface, respectively, in around-the-clock trawl samples. This represents an overall bias towards surface sampling. Given that only $21 \%$ of all Stage III and IV lobsters combined were captured at surface light levels exceeding $100 \mu \mathrm{E} \mathrm{m}^{-2} \mathrm{~s}^{-1}(\sim 12 \mathrm{~h}$, Fig. 6), it follows that our sampling underestimated these lobster stages during daylight. If the majority of well-fed lobster larvae descend below the depth fished by our trawl, or are sufficiently diffused throughout the water column to make capture less frequent during daylight, an erroneous cyclic triacylglycerol/sterol pattern, such as seen in Fig. 6A, could result. It is not possible, therefore, to discount satiation-mediated vertical descent to account for the lower triacylglycerol/sterol ratios found in Stage III and IV lobsters caught during daylight (Fig. 6A).

A third possibility is that the Stage IV lobsters, which are known to have a strong horizontal component to their swimming (Ennis 1986, Cobb et al. 1989, Rooney \& Cobb 1991), actively avoid the trawl during daylight. It is this stage that contributes the most to the daynight signal in the triacylglycerol/sterol ratio, due to their scarcity during daylight. Avoidance of nets and trawls does not appear to occur in the shallower, more- mixed waters off southwestern Nova Scotia and Browns Bank (Stasko \& Gordon 1983) but it may well occur in the more oligotrophic surface waters off the northern edge of Georges Bank, where the majority of the present Stage IV lobsters were captured (Fig. 6B). Cobb et al. (1989) have recorded undisturbed swimming speeds at sea of 7 to $24 \mathrm{~cm} \mathrm{~s}^{-1}$ for Stage IV lobsters. The trawl in the present study was towed as close to $50 \mathrm{~cm} \mathrm{~s}^{-1}$ as possible. However, it is well known that larval lobsters have an entirely different means of propulsion as an avoidance response (Herrick 1911). Stage IV lobsters swim normally by a rhythmic pulsing of the pleopods but respond to the approach of a foreign object by reversing direction by a sudden contraction of the abdomen. Unfortunately there are no measures of this response in the literature. However, studies on larval fish have demonstrated escape speeds of roughly double their average swimming speeds (Williams \& Brown 1992). If this generality applies to other planktonic groups, such as decapods, then the avoidance response of Stage IV lobsters could approach the speed of our trawl. A review of the plankton and larval fish literature indicates that swimming speeds of $50 \mathrm{~cm} \mathrm{~s}^{-1}$ are possible (see Williams \& Brown 1992, Shanks 1995. Williams et al. 1996, Ignatyev 1997. Leis \& Carson-Ewart 1997). Furthermore, an important factor that needs to be considered in this context is the 
distance traveled during such an avoidance response. Again, nothing is known about larval lobster escape distance, but, extrapolating from larval fish of comparable size (Williams et al. 1996), Stage IV lobsters would travel distances of 6 to $16 \mathrm{~cm}$. This suggests that only Stage IV lobsters at the periphery of the trawl mouth, or roughly $30 \%$ of the mouth area, have the possibility of escaping. It is therefore possible that lobsters could have avoided our gear if they could visually detect the trawl and respond by diving beneath or to one side. This might also explain why the Stage IV lobsters caught during daylight were in poorer condition, since they would be less able to escape.

In conclusion, this apparent diurnal cycle of the lipid condition index cannot be explained by nocturnal feeding, which leaves the possibilities that satiated larvae descend below the surface metre during daylight and are therefore underrepresented in our collections by being more vertically diffuse, and/or that healthy well-fed larvae would be more likely to detect the trawl and escape during daylight.

\section{Larval lobster condition and survival}

The lipid condition index increases or decreases with good or bad larval feeding conditions and is thought to reflect their survival potential (Fraser 1989). It has been observed from the laboratory feeding experiments of Sasaki (1984) and the present at-sea collections that the triacylglycerol/sterol ratio in lobster larvae increases after the postmoult period (intramoult Substages A and B; Fig. 3). Sasaki (1984) cultured lobster larvae on Artemia food with (I-series) and without (II-series) fatty acid supplements (cod liver oil) to makeup for known shortcomings of a pure Artemia diet. Growth was consistently greater in larvae raised on the supplemented diet, no matter whether dry weight, protein or lipid aspects of growth were used; thus, only Sasaki's (1984) I-series data sets are illustrated here as a reference to evaluate our field observations (Fig. 7).

Sasaki (1984) starved Stage I and II lobsters in the laboratory and found that when food was withheld between either hatch or moult and early intermoult (intramoult Substage C), individuals did not develop past Stage $D_{0}$, whereas larvae starved from premoult (intramoult Substages $D_{0}$ to $D_{3}$ ) continued their development and moulted, but development was suspended

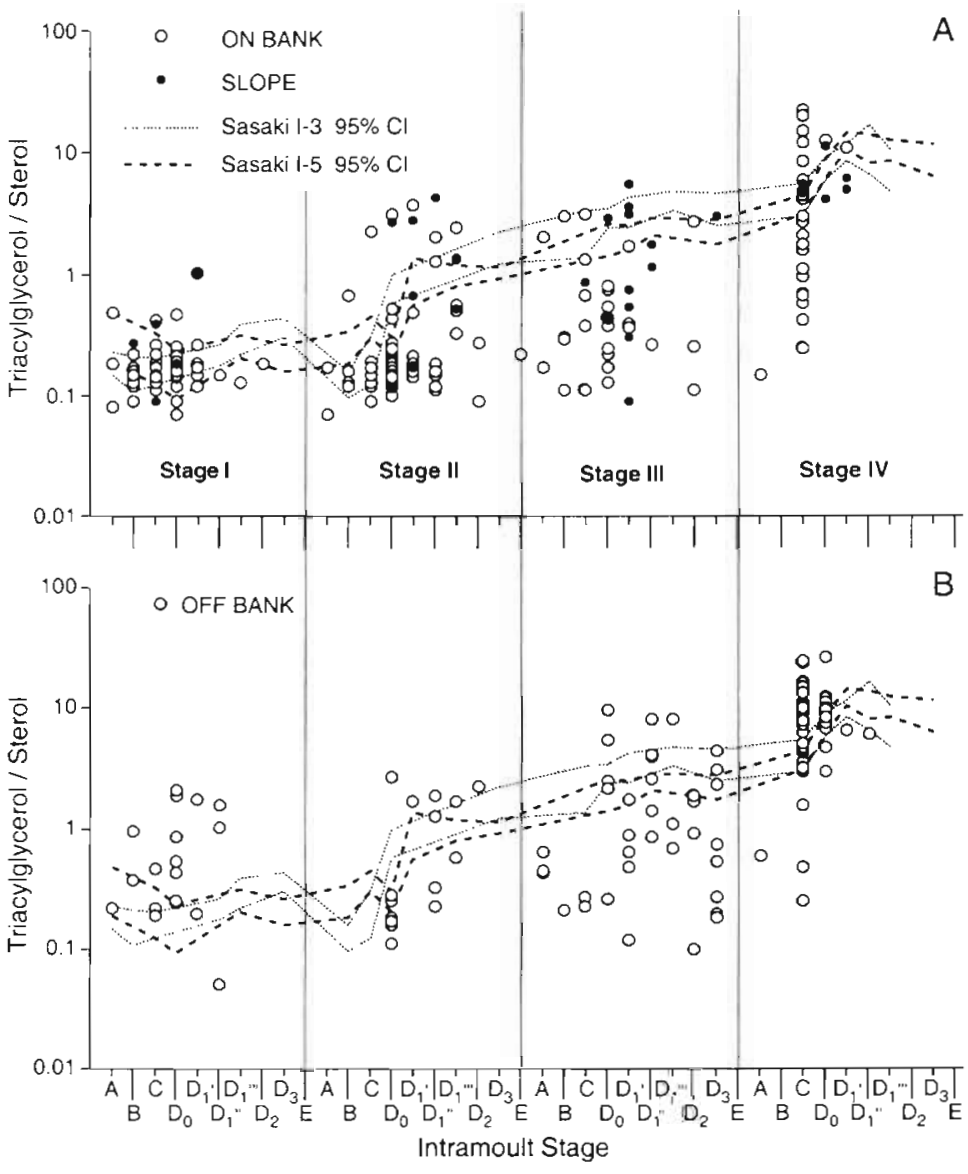

Fig. 7. Comparison of triacylglycerol/sterol values plotted against intramoult stage of lobster larvae collected at sea with those cultured in the laboratory under 'optimal' feeding conditions (see Sasaki 1984). (A) Lobster larvae collected over Georges Bank and along the bank's edge (slope). (B) Lobster larvae collected in the Gulf of Maine in close proximity to Georges Bank. The $95 \%$ confidence intervals for Sasaki's (1984) feeding experiments I-3 and I-5 (code stands for third or fifth day hatch of larvae from female lobster I) are displayed separately in both panels. (Each confidence interval was calculated from only 2 measurements, however, these samples were composites of from 5 Stage I/sample to 2-3 Stage IV/sample)

again by the next intermoult (Stage IIC). This finding is consistent with the $C / D_{0}$ developmental threshold reported in the earlier work on adult lobsters (Aiken 1973) and the $D_{0}$ threshold reported for various crab larvae (Anger \& Dawirs 1981, Dawirs 1986, Anger 1987). The triacylglycerol content of Sasaki's larvae declined rapidly from the first day of starvation, whereas the sterol concentrations remained reasonably constant up to the time when all development ceased ( 4 to $6 \mathrm{~d}$ ). It can be seen that, when these results are expressed as the triacylglycerol/sterol ratio, no matter whether food was withheld from larvae at hatch or $3,4+$ and $7 \mathrm{~d}$ after hatching the ratio dropped below 0.1 by the second day of starvation (Fig. 8 ). The triacylglycerol content of these same larvae was below detec- 


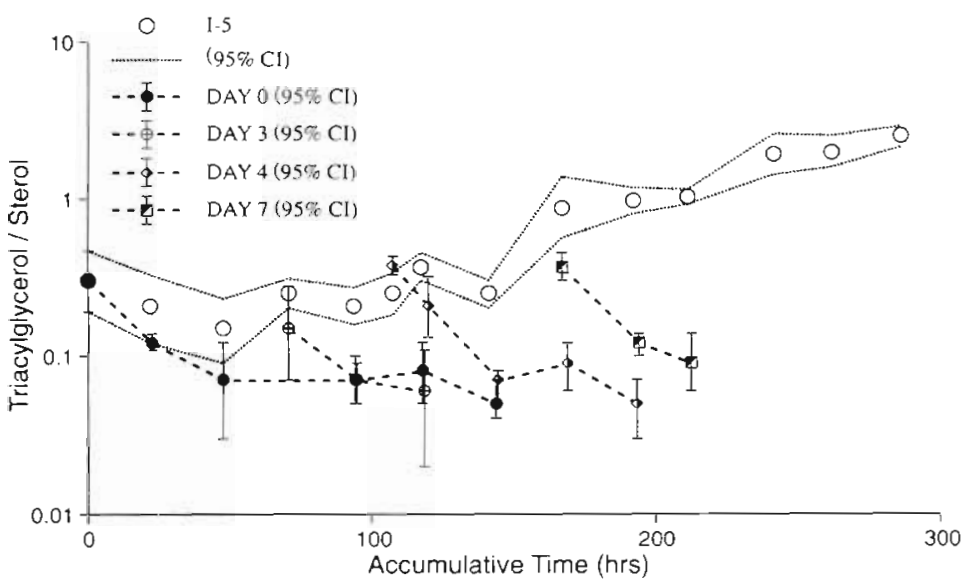

Fig. 8. Larval lobster starvation studies of Sasaki (1984) recalculated to illustrate the effects of fasting on the triacylglycerol/sterol ratio. Batch starvation of larvae, held individually, were started at $0,3,4+$ and $7 \mathrm{~d}$ from hatch from the I-5 culture series. For clarity, the $95 \%$ confidence intervals (CI) are presented as an envelop for the parent culture and as error bars for individual starvation experiments quired under an 'optimal' laboratory feeding situation (Fig. 7B). The Stage IV lobsters residing off the bank in both 1988 and 1989 had significantly higher triacylglycerol/sterol ratios (Kruskal-Wallis 1-way ANOVA) than their counterparts over Georges Bank. Albeit, there were a number of less-than-optimally nourished Stage III lobsters located off the bank. However, these larvae should moult into Stage IV lobsters because they had passed the $C / D_{0}$ developmental threshold described by Sasaki (1984). Judging from the excellent condition of Stage IV larvae located off the bank, the observed poorly nourished Stage III larvae either succumbed to predation before moulting or dramatically increased their nutritional condition in the interim before moulting into stage IV larvae (Fig. 7B) tion limits by the third to fifth day and therefore not seen on the log-plot (Fig. 8). Survival, per se, was not studied in these larvae; however, studies have been carried out on crab larvae which enable us to better interpret Sasaki's laboratory results and our field resuits. Anger \& Dawirs (1981) and Dawirs (1983) studied starvation in Hyas araneus and Carcinus maenas, respectively, and found that larvae must feed shortly after hatching or moulting and subsequently for 20 to $30 \%$ of the normal stage duration for survival of most of the population. This supports the use of the above 0.1 triacylglycerol/sterol level as the minimum survival threshold for lobster larvae to the next moult in laboratory feeding experiments (Sasaki 1984, Fig. 8) and would be equivalent to the 'point-of-no-return' in the larval fish literature (Blaxter \& Hempel 1963). Few Stage I and II lobster larvae were found in the neighbourhood of Georges Bank with a condition index below 0.1 , but this is perhaps not surprising given their poor survival potential from predation and therefore brief existence (Fig. 7).

A number of the larvae collected over Georges Bank, particularly Stages III and IV, either had fed less extensively than well-fed laboratory organisms or had utilized their lipid reserves in searching for prey or avoiding predators (Fig. 7A). There appears to be a preponderance of larvae arrested at the IIID 0 and IVC developmental stages which probably have not acquired sufficient energy reserves to continue development past the $C / D_{0}$ threshold discussed above (see Fig. $7 \mathrm{~A}$ ). This is particularly striking at the IVC intramoult stage. This contrasts with our findings on lobster condition off the bank, where most of the IVC larvae had reserves comparable to or exceeding those ac-

\section{Larval lobster condition and geographic location}

Previous studies suggest that a geographical gradient of larval lobster developmental stages exists between the offshore banks and the surrounding surface waters (Harding et al. 1995). Stage I, II and III Iobsters were found predominantly over Georges Bank, whereas Stage IV lobsters tended to be more abundant in surface waters over the slope into and over the deeper waters of the Gulf of Maine (Table 3). There can be no doubt that the lobsters offshore have evolved the behaviour of releasing their young over shoal waters (Cooper \& Uzmann 1971, Uzmann et al. 1977). It is not entirely understood why this strategy should be an advantage to the species. The condition index reported here is used to evaluate the nutritional condition of larvae found over and off the bank.

It is necessary, however, to first examine the variation measured in triacylglycerol/sterol values to determine which intramoult stages are comparable and therefore can be used to assess larval stage condition at these different geographic locations. As seen in the previous section on larval condition and intramoult stage, the absolute larval triacylglycerol content appears to remain constant or decrease slightly near the moult (Fig. 3i Sasaki 1984). Statistical analyses on Stage I lobsters showed that there was no significant difference in the lipid condition index between intramoult stages (ANOVA and independent $t$-tests on logtransformed data, Kruskal-Wallis 1-way ANOVA). In Stage II lobsters the triacylglycerol/sterol values were significantly lower in intramoult Substages A and B in regard to Stages $D_{0}$ to $D_{1}$, and intramoult Substages $C$ and $D_{0}$ values were lower than Stage $D_{1}$ In Stage III 
Table 3. Larval lobster abundancies (no. $\left./ 10^{4} \mathrm{~m}^{3}\right)$, in 1988 (LH 187 and LH 191) and 1989 (LH 202) combined by stage and location in the Georges Bank Region. SE: standard error

\begin{tabular}{|cccc|}
\hline & On-bank & Slope & Off-bank \\
\hline Stage I lobster & & & \\
$\mathrm{n}$ & $127\left(58^{\mathrm{a}}\right)$ & $32\left(7^{\mathrm{d}}\right)$ & $95\left(9^{\mathrm{d}}\right)$ \\
$\mathrm{X}$ & 7.11 & 4.03 & 1.52 \\
SE & 1.17 & 1.89 & 1.08 \\
Range & $0-70.5$ & $0-50.7$ & $0-100.1$ \\
Stage II lobster & & & \\
$\mathrm{n}$ & $127\left(50^{\mathrm{d}}\right)$ & $32\left(8^{\mathrm{a}}\right)$ & $95\left(16^{\mathrm{d}}\right)$ \\
$\mathrm{X}$ & 3.32 & 1.95 & 0.83 \\
SE & 0.66 & 1.09 & 0.27 \\
Range & $0-46.7$ & $0-33.8$ & $0-16.7$ \\
Stage III lobster & & & \\
$\mathrm{n}$ & $127\left(35^{\mathrm{d}}\right)$ & $32\left(10^{\mathrm{d}}\right)$ & $95\left(22^{\mathrm{d}}\right)$ \\
$\mathrm{X}$ & 2.08 & 1.28 & 1.41 \\
SE & 0.52 & 0.44 & 0.52 \\
Range & $0-42.8$ & $0-8.8$ & $0-38.1$ \\
Stage IV lobster & & & \\
$\mathrm{n}$ & $127\left(19^{\mathrm{d}}\right)$ & $32\left(2^{\mathrm{d}}\right)$ & $95\left(27^{\mathrm{d}}\right)$ \\
$\mathrm{X}$ & 0.44 & 0.51 & 2.17 \\
SE & 0.12 & 0.44 & 0.72 \\
Range & $0-10.3$ & $0-14.0$ & $0-58.0$ \\
aumber of stations with at least 1 lobster larvae captured \\
\hline
\end{tabular}

lobsters, intramoult A, B and C Substages had lower triacylglycerol/sterol values when compared to $D_{1}$. In Stage IV lobsters, intramoult Substage A had significantly lower triacylglycerol/sterol values than Substages $C_{1} D_{0}$ and $D_{1}$. Thus, it can be seen that the variation between intramoult stages is not large or consistent between developmental stages, but it is apparent that it would be best to omit intramoult Substages $\mathrm{A}$ and $\mathrm{B}$ from any geographical comparison because they have consistently lower triacylglycerol/ sterol ratios. If there was a decrease in triacylglycerol/sterol values in Substages $D_{2}$ and $D_{3}$ just prior to the moult, our collections were not extensive enough to show this. Thus, all intramoult Substages C and D are used in the following comparisons between on-bank, off-bank and in-between or slope locations.

The condition of all developmental stages was found to be better in individuals located off Georges Bank in the Gulf of Maine, compared to those captured over the bank, but not significantly different from those over the bank slope (ANOVA on log-transformed data, using the Tukey-Kramer test and Kruskal-Wallis 1-way ANOVA). These results present a dilemma for interpretation. Why would the females with hatching eggs migrate such long distances to release their young over shoal waters if, in fact, the larvae fared better off the bank? Only 1 and $4 \%$ of the Stage I and 4 and $6 \%$ of the Stage II lobsters in the present collections were col- lected at slope and off-bank locations, respectively. None of the Stage I lobsters were found further than $5 \mathrm{n}$ miles from the bank edge. From these low abundances off the bank, larval release there appears to be an error of nature and could be explained by either a small number of developmentally advanced larvae hatching prematurely as their mothers approach the 'spawning' and mating grounds or, alternately, by a rare but substantial displacement of surface water and larvae off the bank. Pandian (1970) reported that earlyhatching lobster larvae had a greater energy reserve and that the calorific content of eggs hatched from the same female declined on 4 successive nights. This observation is supported by the work of Wickins et al. (1995) on the European lobster Homarus gammarus; they found that triacylglycerol reserves were $15 \%$ higher in first-hatching larvae. This could aptly explain why the few Stage I lobsters collected off Georges Bank were in above-average condition, assuming that they were prematurely released as their mothers approached the bank.

There are several environmental variables which are thought to convey an advantage to bank hatching. The shoaler bottom waters are warmer, which increases the development rate and stimulates hatching, however, the surface waters that receive these larvae are, in fact, cooler due to the strong tidal mixing action, compared to the warm, highly stratified waters over the Gulf of Maine. Also, Sasaki et al. (1986) concluded from laboratory hatchings at ambient and elevated temperatures that lobster embryos utilized lipids more efficiently at higher temperatures. Obviously, lobster larvae starting with greater triacylglycerol reserves, either from being the first to hatch (Pandian 1970, Wickins et al. 1995) or by originating from warmer bottom waters (Sasaki et al. 1986), would have a survival advantage over larvae developing under different circumstances. Storage lipids in posthatch larvae presumably enable a grace period for locating prey. The question of prey availability and size is probably the most important reason for shoal water release of larvae. A prolific smaller copepod, prey community exists over the banks which would be beneficial for the growth of the earlier development stages of the lobster (Harding et al. 1983). A disadvantage of spawning at Georges Bank would be that the extensive vertical tidal mixing would carry the larvae away from their optimal depth in the water column which, depending on the time of the day (Harding et al. 1987), would require them to utilize energy reserves to maintain depth.

Stage III and IV lobsters collected at the periphery and off the edge of Georges Bank not only contained a higher proportion of storage lipid but Stage IV lobsters were more abundant there than over the bank (Table 3). It is not understood why this last plank- 
tonic/pelagic stage of the lobster appears to be more numerous in the warmer, stratified waters of the Gulf of Maine compared to Georges Bank, nor is it clear why they possess greater energy reserves than individuals remaining over the bank. It is reasonable to believe that the fatter individuals are better able to make a successful transition to benthic life at the end of Stage IV. As discussed previously, the warmer temperature may assist in a more efficient utilization of lipid reserves (Sasaki et al. 1986). The surface plankton community is sparse off the bank and does not compare to the rich food source over the bank at this time of year (Perry et al. 1993). Although a deeper-living Calanus community exists off the bank, it does not appear to overlap with the surface distribution of the lobster because the vertical migration of Calanus does not penetrate the strong thermocline during the summer (Perry et al. 1993). Georges Bank is teaming with fish predators and invertebrate competitors in the summer (Avery et al. 1996, Sullivan \& Meise 1996), which could cause the advanced stages of lobster remaining over the bank to utilize excessive amounts of their energy reserves in avoidance behaviour. If the lobster has evolved a migration off Georges Bank during and after Stage III, as the present results suggest, it is not clear how they are able to pass through the strong tidal front surrounding the bank (Loder et al. 1993). The origin of the off-bank Stage III and IV lobsters is unknown, but is thought to be most likely from the western sector of Georges Bank, the nearest source, because of the strong current along the northern face of the bank (Loder et al. 1992). However, it is possible that some or all come from further 'upstream' in the Cape Cod or Nantucket Shoals regions.

\section{CONCLUSION}

Deep-water lobsters sometimes migrate considerable distances in the spring and early summer to release their larvae in the shoal waters over Georges Bank. The evolutionary significance of this behaviour is thought to lie in the energy rewards gained from larval feeding on the sustained high summer production over the bank, compared to the oligotrophic conditions which develop in the Gulf of Maine following the spring bloom and increased stratification. The last planktonic/pelagic stage of the lobster, however, was more abundant and had a higher condition index in these oligotrophic waters on the periphery of the Gulf of Maine, which suggests that they are somehow able to utilize the rich planktonic community which exists beneath the thermocline. It appears then that the larval stages of the lobster also have a dispersive function for the species, although it is not known whether they penetrated the strong tidal front on the northern edge of Georges Bank to reach the deeper waters of the Gulf of Maine or originated from 'upstream' sources off Nantucket Shoals or Cape Cod Bay (Limeburner \& Beardsley 1996).

Acknowledgements. We would like to thank our coinvestigators Ken Drinkwater, Ian Perry, John Pringle and John Tremblay of the Georges Bank Frontal Study, under which umbrella this study was conveniently nestled, for collaboration at sea. It is a pleasure to thank Peter Vass for an exceptional job in the planning, preparation and operation of the 3 cruises aboard the 'Lady Hammond' from which the present data set was derived. Many thanks to Peter Vass and Dwight Reimer for the development, maintenance and operation of the Vass-Tucker trawl used in collecting larval lobsters. We would also like to thank the following additional people for assistance at sea: Randy Losier, Jim Reid and Scott Wilson. Walton Watt kindly gave us statistical advice on combining the variances of products. Ken Drinkwater and Ken Mann kindly consented to do an interndl departimental review of our manuscript. Bob Miller, Sifford Pearre Jr, Patrick Ouellet and 3 anonymous referees made many helpful comments on earlier drafts of this manuscript. Finally, we would like to thank Captain Neil Barnes and the crew of the 'Lady Hammond' tor their professiondi commitment to our rigorous around-the-clock sampling programme.

\section{LITERATURE CITED}

Ackman RG (1981) Flame ionization detection applied to thinlayer chromatography on coated quartz rods. Methods Enzymol 72:205-252

Aiken DE (1973) Proecdysis, setal development, and molt prediction in the American lobster (Homarus americanus). J Fish Res Board Can 30:1337-1344

Anger $K$ (1987) The $D_{0}$ threshold: a critical point in the larval development of decapod crustaceans. J Exp Mar Biol Ecol 108:15-30

Anger K, Dawirs RR (1981) Influence of starvation on the larval development of Hyas araneus (Decapoda, Majidae). Helgol Meeresunters 34:287-311.

Anger K, Harms J, Puschel C, Seeger B (1989) Physiological and biochemical changes during the larval development of a brachyuran crab reared under constant conditions in the laboratory. Helgol Meeresunters 43:225-244

Avery DE, Green J, Durbin EG (1996) The distribution and abundance of pelagic gammarid amphipods on Georges Bank and Nantucket Shoals. Deep-Sea Res II 43: $1521-1532$

Bamstedt U, Hakanson JL, Brenner-Larsen J, Bjornsen PK. Geertz-Hansen O, Tiselius P (1990) Copepod nutritional condition and pelagic production during autumn in Kosterfjorden, western Sweden. Mar Biol 104:197-208

Blaxter JHS, Hempel G (1963) The influence of egg size on herring larvae (Clupea harengus L.). J Conseil 28:211-240

Bloch KE (1983) Sterol structure and membrane function. CRC Crit Rev Biochem 14:47-92

Buckley LJ, Lough RG (1987) Recent growth, biochemical composition, and prey field of larval haddock (Melanogrammus aeglefinus) and Atlantic cod (Gadus morhua) on Georges Bank. Can J Fish Aquat Sci 44:14-25

Chandumpai A, Dall W, Smith DM (1991) Lipid-class compo- 
sition of organs and tissues of the tiger prawn Panaeus esculentus during the moulting cycle and during starvation. Mar Biol 108:235-245

Cobb JS, Wang D, Campbell DB, Rooney P (1989) Speed and direction of swimming by postlarvae of the American lobster Trans Am Fish Soc 118:82-86

Cohen RE, Lough RG, Murphy JA (1980) Larval herring (Clupea harengus L.) gut content and morphological condition data from three spawning seasons (1974, 1975, and 1976) in the Georges Bank - Gulf of Maine area. NAFO SCR Doc 80/IX/134

Cooper RA, Uzmann JR (1971) Migrations and growth of deep-sea lobsters, Homarus americanus. Science 171. $288-290$

Dawirs RR (1983) Respiration, energy balance and development during growth and starvation of Carcinus maenas $L$. larvae (Decapoda: Portunidae). J Exp Mar Biol Ecol 69 $105-128$

Dawirs RR (1986) Influence of limited food supply on growth and elemental composition $(\mathrm{C}, \mathrm{N}, \mathrm{H})$ of Carcinus maenas (Decapoda) larvae, reared in the laboratory. Mar Ecol Prog Ser 31:301-308

Drinkwater KF, Graca MJ, Loder JW (1992) Lagrangian current measurements from the Georges Bank frontal study, 1988-89. Part 1: Drift buoy trajectories. Can Data Rep Hydrogr Ocean Sci 116

Ennis G (1986) Swimming ability of larval American lobsters, Homarus americanus, in flowing water. Can J Fish Aquat Sci 43:2177-2183

Ferron A, Leggett WC (1994) An appraisal of condition measures for marine fish larvae. Adv Mar Biol 30:217-303

Fogarty MJ, Borden DVD, Russell HJ (1980) Movements of tagged American lobster, Homarus americanus, off Rhode Island. Fish Bull 78:771-780

Frank KT, McRuer JK (1989) Nutritional status of field-collected haddock (Melanogrammus aeglefinus) larvae from southwestern Nova Scotia: an assessment based on morphometric and vertical distribution data. Can J Fish Aquat Sci 46(Suppl): 125-133

Fraser AJ (1989) Triacylglycerol content as a condition index for fish, bivalve, and crustacean larvae. Can J Fish Aquat Sci 46:1868-1873

Fraser AJ, Tocher DR, Sargent JR (1985) Thin-layer chromatography-flame ionization detection and the quantification of marine neutral lipids and phospholipids. J Exp Mar Biol Ecol 88:91-99

Fraser AJ, Sargent JR, Gamble JC, MacLachlan P (1987) Lipid class and fatty acid composition as indicators of the nutritional condition of larval Atlantic herring. Am Fish Soc Symp 2:129-143

Fraser AJ, Gamble JC, Sargent JR (1988) Changes in lipid content, lipid class composition and fatty acid composition of developing eggs and unfed larvae of cod (Gadus morhua). Mar Biol 99:307-313

Fraser AJ, Sargent JR, Gamble JC (1989) Lipid class and fatty acid composition of Calanus finmarchicus (Gunnerus), Pseudocalanus sp. and Temora longicornis Muller from a nutrient-enriched seawater enclosure. J Exp Mar Biol Ecol 130:81-92

Goodwin TW (1960) Biochemistry of pigments. In: Waterman TH (ed) The physiology of crustacea. 1. Metabolism and growth. Academic Press, London, p 101-140

Hakanson JL (1989a) Analysis of lipid components for determining the condition of anchovy larvae, Engraulis mordax. Mar Biol 102:143-151

Hakanson JL (1989b) Condition of larval anchovy (Engraulis mordax) in the southern California Bight, as measured through lipid analysis. Mar Biol 102:153-159

Harding GC, Trites RW (1988) Dispersal of Homarus americanus larvae in the Gulf of Maine from Browns Bank. Can J Fish Aquat Sci 45:416-425

Harding GC, Trites RW (1989) A further elaboration on 'Dispersal of Homarus americanus larvae in the Gulf of Maine from Browns Bank,' in response to comments by D.S. Pezzack. Can J Fish Aquat Sci 46:1077-1082

Harding GC, Drinkwater KF, Vass WP (1983) Factors influencing the size of American lobster (Homarus americanus) stocks along the Atlantic coast of Nova Scotia, Gulf of St. Lawrence, and Gulf of Maine: a new synthesis. Can J Fish Aquat Sci 40:168-184

Harding GC, Pringle JD, Vass WP, Pearre S Jr, Smith SJ (1987) Vertical distribution and daily movements of larval lobsters Homarus americanus over Browns bank, Nova Scotia. Mar Ecol Prog Ser 41:29-41

Harding GC, Drinkwater KF, Pringle JD. Fraser AJ, Prena J, Pearre S Jr, Perry RI, Vass WP (1995) Studies on the effect of the frontal zone on the northern face of Georges Bank, Gulf of Maine, on larval lobster and plankton distribution. ICES Annu Sci Conf Q:1-18

Hardy AC, Gunther ER (1936) The plankton of the South Georgia whaling ground and adjacent waters, 1926-27. Discovery Rep 11:1-456

Herrick. FH (1911) Natural history of the American lobster Bull Bureau Fish 29:149-408

Herring PJ (1972) Depth distribution of the carotenoid pigments and lipids of some oceanic animals. 1. Mixed zooplankton, copepods and euphausiids. J Mar Biol Assoc UK 52:179-189

Huntley M. Brooks ER (1982) Effects of age availability on diel vertical migration of Calanus pacificus. Mar Biol 71 : 23-31

Ignatyev SM (1997) Pelagic fishes and their macroplankton prey: swimming speeds. In: Proceedings of the international symposium on the role of forage fishes in marine ecosystems. Alaska Sea Grant College Program, Anchorage, AK-SG-97-01, p 31-39

Juinio MAR, Cobb JS (1992) Natural diet and feeding habits of the postlarval lobster Homarus americanus. Mar Ecol Prog Ser 85:83-91

Katz CH, Cobb JS, Spaulding M (1994) Larval behavior, hydrodynamic transport, and potential offshore-to-inshore recruitment in the American lobster Homarus americanus. Mar Ecol Prog Ser 103:265-273

Keen JN, Caceres I, Eliopoulos EE, Zagalsky PF, Findlay JBC (1991) Complete sequence and model for the $A_{2}$ subunit of the carotenoid pigment complex, crustacyanin. Eur J Biochem 197:407-417

Koslow JA, Brault S, Dugas J, Fournier RO, Hughes P (1985) Condition of larval cod (Gadus morhua) off southwest Nova Scotia in 1983 in relation to plankton abundance and temperature. Mar Biol 86:113-121

Leis JM, Carson-Ewart BM (1997) In situ swimming speeds of the late pelagic larvae of some Indo-Pacific coral-reef fishes. Mar Ecol Prog Ser 159:165-174

Limeburner R, Beardsley RC (1996) Near-surface recirculation over Georges Bank. Deep-Sea Res II 43:1547-1574

Lochmann SE, Maillet GL, Frank KT, Taggart CT (1995) Lipid class composition as a measure of nutritional condition in individual larval Atlantic cod (Gadus morhua). Can J Fish Aquat Sci 52:1294-1306

Loder JW, Brickman D, Horne EPW (1992) Detailed structure of currents and hydrography on the northern side of Georges Bank. J Geophys Res 97:14331-14351

Loder JW, Drinkwater KF, Oakey NS, Horne EPW (1993) Cir- 
culation, hydrographic structure and mixing at tidal fronts: the view from Georges Bank. Philos Trans $R$ Soc Lond A 343:447-460

Lovrich GA, Ouellet P (1994) Patterns of growth and triacylglycerol content in snow crab Chionoecetes opilio (Brachyura: Majidae) zoeal stages reared in the laboratory. Mar Biol 120:585-591

Ouellet P, Taggart CT, Frank KT (1992) Lipid condition and survival in shrimp (Pandalus borealis) larvae. Can J Fish Aquat Sci 49:368-378

Ouellet P, Taggart CT, Frank KT (1995) Early growth, lipid composition, and survival expectations of shrimp Pandalus borealis larvae in the northern Gulf of St. Lawrence. Mar Ecol Prog Ser 126:163-175

Pandian TJ (1970) Yolk utilization and hatching time in the Canadian lobster Homarus americanus. Mar Biol 7: $249-254$

Pearre S Jr (1973) Vertical migration and feeding in Sagitta elegans Verrill. Ecology 54:300-314

Pearre S Jr (1979) Problems of detection and interpretation of vertical migration. J Plankton Res 1:29-44

Perry Ri, hal ding GC, Loder JW, Tremblay MJ, Sinclair MM Drinkwater KF (1993) Zooplankton distributions at the Georges Bank frontal system; retention or dispersion? Cont Shelf Res 13:357-383

Peters RH (1983) The ecological implications of body size. Cambridge University Press, Cambridge.

Rogers BA, Cobb JS, Marsha]] N (1968) Size comparisons of inshore and offshore larvae of the lobster, Homarus americanus, off southern new England. Proc Natl Shellfish Assoc 58:78-81

Rooney P, Cobb JS (1991) Effects of time of day, water temperature, and water velocity on swimming by postlarvae of the American lobster, Homarus americanus. Can J Fish Aquat Sci 48:1944-1950

Sargent JR, Whittle KJ (1981) Lipids and hydrocarbons in the marine food web. In: Longhurst AR (ed) Analysis of marine ecosystems. Academic Press, London, p 491-533

Sasaki GC (1984) Biochemical changes associated with embryonic and larval development in the American lobster Homarus americanus Milne Edwards. PhD thesis, Massachusetts Institute of Technology, Cambridge, and Woods Hole Oceanographic Institution, Woods Hole, MA, WHOI-84-8

Sasaki GC, Capuzzo, JM (1984) Degradation of Artemia lipids under storage. Comp Biochem Physiol 78B:525-531

Sasaki GC, Capuzzo JM, Biesiot P (1986) Nutritional and bioenergetic considerations in the development of the American lobster Homarus americanus. Can J Fish Aquat Scj 43:2311-2319

Shanks AL (1995) Oriented swimming by megalopae of several eastern North Pacific crab species and its potential

Editorial responsibility: Otto Kinne (Editor),

Oldendorf/Luhe, Germany role in their onshore migration. J Exp Mar Biol Ecol 186: $1-16$

Stasko AB (1978) Inshore-offshore SW Nova Scotia lobster stock interaction: a hypothesis. Can Atl Fish Sci Adv Comm Res Doc 78/37

Stasko AB, Gordon DJ (1983) Distribution and relative abundance of lobster larvae off southwestern Nova Scotia 1977-1978. Can Tech Rep Fish Aquat Sci 1175

Sullivan BK, Meise CJ (1996) Invertebrate predators of zooplankton on Georges Bank, 1977-1987. Deep-Sea Res II 43:1503-1519

Suthers IM, Fraser A, Frank KT (1992) Comparison of lipid, otolith and morphometric condition indices of pelagic juvenile cod Gadus morhua from the Canadian Atlantic. Mar Ecol Prog Ser 84:31-40

Tremblay MJ, Loder JW, Werner FE, Naimie CE, Page FH, Sinclair MM (1994) Drift of sea scallop larvae Placopecten magellanicus on Georges Bank: a model study of the roles of mean advection, larval behavior and larval origin. Deep-Sea Res II 41:7-49

Uzmann JR, Cooper RA, Pecci KJ (1977) Migration and dispersion of tagged American lobsters, Homarus americanus, on the southern New England continental shelt. US Dept of Commerce, NOAA Tech Rep NMFS SSRF705:1-92

Vass P (1988) Modified Tucker trawl for larval lobster studies. Lobster Newsletter 1:6-7

Watson FL, Miller RJ (1991) Distribution of lobster larvae on the Scotian Shelf: 1978-1981. Can Tech Rep Fish Aquat Sci 1801

Wickins JF, Beard TW, Child AR (1995) Maximizing lobster, Homarus gammarus (L.), egg and larval viability. Aquacult Res 26:379-392

Wilkinson L (1992) SYSTAT: Statistics, Version 5.2 Edition. SYSTAT Inc, Evanston, IL

Williams LW (1907) The stomach of the lobster and the food of larval lobsters. 37th Annu Rep Com Inland Fish, Providence, RI, p 155-180, Figs. 1-16

Williams PJ, Brown JA (1992) Development changes in the escape response of larval winter flounder Pleuronectes americanus from hatch through metamorphosis. Mar Ecol Prog Ser 88:185-193

Williams PJ, Brown JA, Gotceitas V, Pepin P (1996) Development changes in escape response performance of five species of marine larval fish. Can J Fish Aquat Sci 53: 1246-1253

Williamson DI (1969) Names of Jarvae in the Decapoda and Euphausiacea. Crustaceana 16:210-213

Zagalsky PF, Eliopoulos EE, Findlay JBC (1991) The lobster carapace carotenoprotein, a-crustacyanin. A possible role for tryptophan in the bathochromic spectral shift of protein-bound astaxanthin. Biochern J 274:79-83

Submitted: March 3, 1998; Accepted: April 12, 1999

Proofs received from author(s): August 30, 1999 